\title{
Use of Otoliths to Estimate Size at Sexual Maturity in Fish
}

\author{
Carlos Sérgio Agostinho \\ Fundação Universidade do Tocantins - R. Luiz Leite Ribeiro/Av. Castelo Branco, Setor Aeroporto, CEP 77500-000, \\ Porto Nacional - TO, Brazil
}

\begin{abstract}
The viability of an alternative method for estimating the size at sexual maturity of females of Plagioscion squamosissimus (Perciformes, Sciaenidae) was analyzed. This methodology was used to evaluate the size at sexual maturity in crabs, but has not yet been used for this purpose in fishes. Separation of young and adult fishes by this method is accomplished by iterative adjustment of straight-line segments to the data for length of the otolith and length of the fish. The agreement with the estimate previously obtained by another technique and the possibility of calculating the variance indicates that in some cases, the method analyzed can be used successfully to estimate size at sexual maturity in fish. However, additional studies are necessary to detect possible biases in the method.
\end{abstract}

Key words: Otolith, Sexual maturity, Plagioscion squamosissimus

\section{INTRODUCTION}

Knowledge of the mean size at which individuals reach sexual maturity is basic information for the control of exploitative fishing of young individuals, and when associated with other information aids in evaluation and prediction of fish stocks (Agostinho, 1985). Size at first sexual maturity in fish is influenced by genetic, physiological, and environmental factors (Nikolskii, 1969). There is no exact size after which sexual maturation begins, therefore we adopted as size at first sexual maturity, that at which $50 \%$ of the individuals constituting a population have entered the gonadal maturity stage (Vazzoler, 1996).

Estimation of size at sexual maturity has been made from the frequency distribution of adult individuals per length class (Somerton, 1981). This is dependent on the accurate separation of young and adult individuals. In fishes, young individuals are distinguished based on the degree of gonadal maturity. The main difficulty of this method is separating adolescent individuals from those which are beginning a new reproductive cycle. Somerton (1980a) proposed a method for separating young and adult crabs, based on the diphasic growth of the chela and carapace. We analyze the viability of the method proposed by Somerton (1980a), for estimating the size at sexual maturity of females of Plagioscion squamosissimus.

\section{MATERIAL AND METHODS}

Curvines, Plagioscion squamosissimus (Heckel, 1940), were caught in the Itaipu Reservoir (Brazil) from November 1983 through February 1989, using stationary nets of mesh size 3-16 cm, measured between opposite knots. A total of 263 sagittal otoliths were used to estimate size at first maturity of females of $P$. squamosissimus. The estimates of size at first maturity and of its variance were made using the computational program developed by Somerton (1980a).

The method proposed by Somerton (1980a) for estimating the size at sexual maturity is described as follows: 1) two values of $X$, a juvenile bound and an adult bound, are chosen such that the $\mathrm{X}$ axis is divided into three regions; the leftmost region containing data only from individuals known to be juveniles, the rightmost region containing data only from individuals known to be adults, and the middle region containing data for an unknown mixture of juveniles and adults. Preliminary estimates of the two phase lines are made by fitting straight lines, using linear regression, to the known juvenile and adult data. The lines are extrapolated into the middle region and the difference in $\mathrm{Y}$ direction between every 
data point in the middle region and each of the two lines is calculated. Data points are then tentatively assigned to the closet line, that is, they are tentatively classified as either juvenile or adult and combined with the data with known maturity. The phase lines are recomputed, the distance between every point in the middle region and each of the lines is recalculated, and the points are again assigned to the closest line. This process is repeated iteratively until no points switch from one phase line to another on two successive iterations; 2) after the iterative process converges, a statistical test is made to determine if the resulting two lines fit the data better than a single line (Draper and Smith, 1966). If the fit is not significantly better, there is little justification for using two lines to describe the data and, consequently, some other method must be used to determine sexual maturity; 3 ) to estimate the size of $50 \%$ sexual maturity, the $\mathrm{X}$ axis is transformed back to a linear scale and divided into a number of equal-width size intervals. For each interval, the proportion of the data classified as mature is determined. A logistic function (Berkson, 1944) is fitted to these proportions and the resulting equation is then evaluated to find the size at which $50 \%$ of the individuals are mature.

According to Somerton (1980a), the total variance of the estimate for size at first maturity has two components of variability. One component stems from the probability of classifying morphometric data into the wrong maturity category (misclassification error), that is, to consider a datum as pertaining to a juvenile individual when actually it pertains to an adult, or vice versa. The other component stems from the error in fitting the logistic curve to the data (fitting error).

Of the two components of total variance, only the fitting error could be estimated by standard statistical methods. This estimate was described by Seber (1973, in Somerton, 1980b) as the Delta Method.

The mean fitting error and the total variance were calculated for both sexes combined, using the MATURE program (Somerton, 1980a). These estimates were made for random subsamples with the same number of data points, with reposition and with at least 23 replicates, for $\mathrm{N}$ subsamples of different sizes. To avoid possible underestimation of variance because of reposition, we used subsamples with at most 300 of the total of 544 data points.

To the total variances, we fitted an exponential curve estimated as a function of the sample sizes, by the method of nonlinear least squares, using Statistic software. The equation fitted is expressed as: $\mathrm{y}=\mathrm{a} /\left(1+\mathrm{b} \exp ^{-\mathrm{cx}}\right)^{\mathrm{d}}$ where $\mathrm{y}$ is the total variance, $\mathrm{x}$ is the size of the subsamples, and a,b,c, and $d$ are constants. The estimation of the variance for the whole sample was then obtained by extrapolating this curve to the desired sample size. The misclassification error can be inferred by subtracting the fitting error from the total variance.

\section{RESULTS}

The fit of two straight lines to the data for the relationship between otolith length and standard body length of females of $P$. squamosissimus was better than the fit of only one line $(\mathrm{F}=101.71$, $\mathrm{df}=2 ; 259, \mathrm{P}<0.001)$. Thus, there is a reduction in the increment of otoliths above a given fish length (Fig. 1).

length (OL) and standard body length (SL) in females of $P$. squamosissimus.

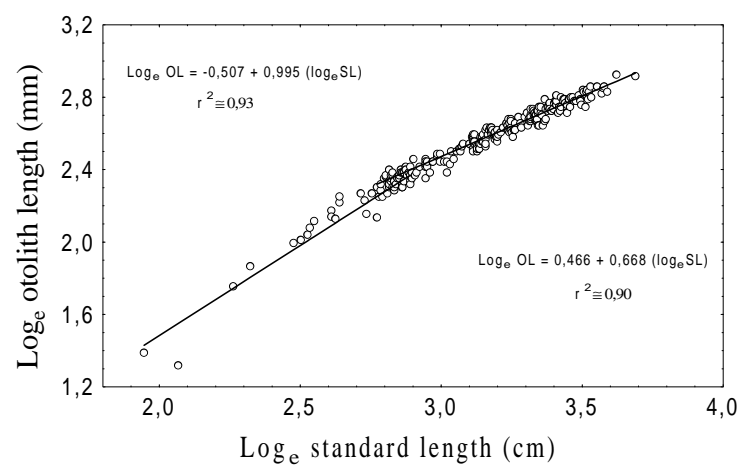

Figure 1. Allometric relationship between otolith

The size at first maturity estimated from the logistic equation for females of $P$. squamosissimus was $17.8 \pm 1.63 \mathrm{~cm}$ (Fig. 2). 


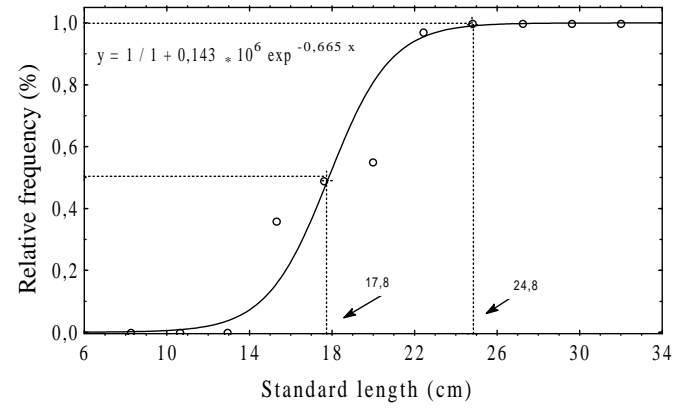

Figure 2. Relative frequency of adults per standard length class for females of P. squamosissimus.

The total variance decreased sharply with increasing subsample size. The fitting error remained constant above the subsample with 75 data points, contributing approximately $40 \%$ of the total variance. Although the total variance did not stabilize, it was less than 1 above a subsample with 150 data points, probably because of the reduction of misclassification error (Figs. 3 and 4).

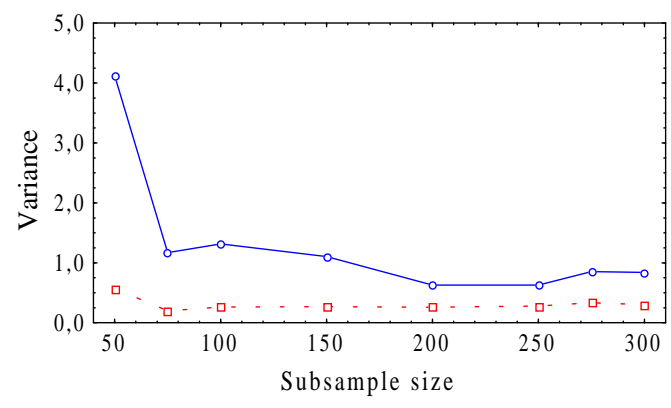

Figure.3. Total variance (solid line) and fitting error (dotted line) of the estimate of size at first maturity for both sexes combined of $P$. squamosissimus, as a function of sample size.

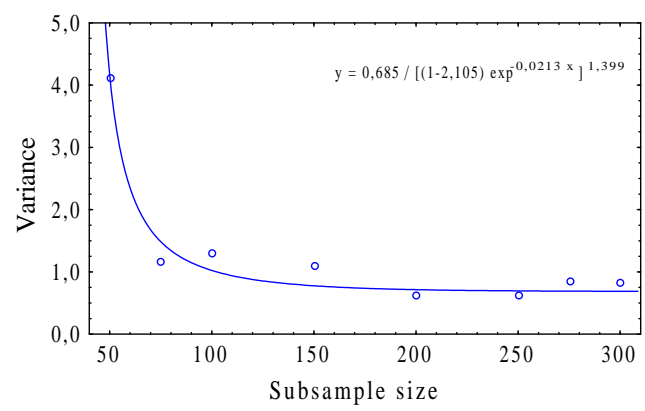

Figure 4. Logistic equation adjusted for total variance of the estimate of size at first maturity for both sexes combined of $P$. squamosissimus, as a function of sample size.

\section{DISCUSSION}

The fit of two straight lines to the data for the relationship between otolith length and standard body length for females of $P$. squamosissimus was better than the fit of only one straight line $(\mathrm{p}<0.001)$. Worthmann (1979), studying the same species in the Amazon basin, fitted only one straight line to the data, probably because of the short range of lengths which he analyzed.

The content of calcium carbonate and organic matter deposited in the otoliths depended on the type of food and the habitat in which the fish lived (Worthmann, 1979). The change in feeding habits of $P$. squamosissimus following sexual maturation (Hahn, 1991) might be one of the factors responsible for the allometric growth of the otoliths. Another hypothesis could be that with initiation of sexual maturation, part of the minerals and organic matter which made up the otoliths could be used to any number of alternative investments of energy (e.g., into cortship and nest care). Wootton (1990) noted that there might be reduction in somatic growth with initiation of sexual maturity, because energy is diverted to the gonads.

Estimation of the size at sexual maturity by the method described by Somerton (1980a) presupposed that allometric growth of the otolith was a result of sexual maturation of the individuals. Eziuzo (1963), Cunningham (1978), and Soares (1982) suggested that the change in otolith growth was related to sexual maturation of individuals. Guerra and Sánchez (1985) also observed this for statoliths of cephalopods.

Martin (1949) found five lines of relative growth for Atlantic salmon and this growth pattern might be generalized to a greater or lesser degree for all species of fishes. The four inflection points which delimited these lines coincided approximately with eye formation in the egg phase, hatching, bone development, and sexual maturation. Other investigators who have not studied all the phases of development have found only two relative growth lines. In these cases the inflection corresponded to sexual maturation.

For calculation of variance, it is desirable to make random subsamples without reposition, and with at least seven replicates; however, this requires large samples. The variance curve shown was estimated for both sexes combined, from random subsamples with reposition, which may have underestimated the variance for the larger subsample sizes.

The method analyzed eliminated subjectivity in separating juveniles and adults when this 
separation was done only by macroscopic analysis of the gonads. However, when the relative growth lines were not well separated, the classification error might be high, therefore restricting the use of this method (Somerton, 1980a).

The size at first maturity of females of $P$. squamosissimus, estimated from the degree of gonadal maturity, was $15.9 \mathrm{~cm}$ (Vazzoler et al., 1996). This matched with $17.8 \pm 1.68 \mathrm{~cm}$ derived using otolith data. The nearness of the estimates using the two methods and the possibility of calculating the variance indicated that in some cases the method proposed by Somerton (1980a) could be successfully used to estimate the size at first sexual maturity in fishes. However, this alternative method needs to be evaluated through additional investigations in order to detect possible biases.

\section{ACKNOWLEDGEMENTS}

We thank the multidisciplinary team of Research Nucleus in Limnology, Ichthyology and Aquaculture (NUPELIA) for the data and support.

\section{RESUMO}

A viabilidade de uma metologia alternativa para a estimativa do tamanho de maturação sexual de fêmeas de Plagioscion squamosissimus (Perciformes, Sciaenidae) foi analisada. Esta metodologia tem sido utilizada para avaliar o tamanho da maturação sexual em caranguejos mas ainda não havia sido utilizada em peixes com este objetivo. A separação dos peixes jovens e adultos por este método é feita pelo ajuste iterativo de segmentos de reta aos dados de comprimento do otólito e comprimento do peixe. A concordância com a estimativa obtida previamente utilizando outra técnica e a possibilidade do cálculo da variância indica que em alguns casos o método analisado pode ser utilizado com sucesso para estimar o tamanho de maturação sexual em peixes, mas outros estudos são necessários para se detectar possíveis bias do método.

\section{REFERENCES}

Agostinho, A.A. (1985), Estrutura da população, idade, crescimento e reprodução de Rhinelepis aspera (Agassiz, 1829) (Osteichthyes, Loricariidae) do rio Paranapanema, PR. Tese de Doutorado. Universidade Federal de São Carlos. 229
Berkson, J. (1944), Application of the logistic function to bioassay. J. Am. Stat. Assoc., 39: 357-365

Cunningham, P.T.M. (1978), Bionomia e ciclo de vida de Ctenosciaena gracilicirhus (Metzelaar, 1919) na plataforma continental brasileira entre as latitudes de $22^{\circ} 10^{\prime} \mathrm{S} e 30^{\circ} \mathrm{S}$. Dissertação de Mestrado. Universidade de São Paulo, Instituto Oceanográfico, 106

Draper, N.R. \& Smith. H. (1966), Applied regression analysis. John Wiley and Sons, Inc., New York. 407

Eziuzo, E.N.C. (1963), The identification of otoliths from West African demersal fish. Bull. Inst. Fr. Afr. Noire, Ser. A., 25(2): 488-512

Guerra, A. \& Sánchez, P. (1985), Crecimento relativo del estatolito de Sepia officinalis (Cephalopoda, Sepioidea) de la ría Vigo. Inv. Pesq. 49(4): 545-557

Hahn, N.S. (1991), Alimentação e dinâmica da nutrição de curvina Plagioscion squamosissimus (Heckel, 1840) (Pisces, Perciformes) e aspectos da estrutura trófica da ictiofauna acompanhante no rio Paraná. Rio Claro: UNESP. Tese de Doutorado. 287

Martin, W.R. (1949), The mechanics of environmental control of body form in fishes. Univ. Toronto Studies Biol. Publ. Ont. Fish. Res. Lab., 7:1-91

Nikolskii, G.V. (1969), Theory of Fish Population Dynamics. Oliver and Boyd, Edinburgh. 323

Soares, L.S.H. (1982), Aspectos da biologia e ecologia de Isopisthus parvipinnis (Cuvier, 1830) (Perciformes:Sciaenidae) entre Cabo Frio e Torres, Brasil. Dissertação de mestrado. Universidade de São Paulo, Instituto Oceanográfico. 123

Somerton, D.A. (1980a), A computer technique for estimating the size of sexual maturity in crabs. Can. J. Fish. Aquat. Sci., 37: 1488-1494

Somerton, D.A. (1980b), Fitting straight lines to Hiatt growth diagrams: a re-evaluation. Cons. Int. Explor. Mer., 39(1): 15-19

Somerton, D.A. (1981), Regional variation in the size of maturity of two species of tanner crab (Chionoecetes bairdi and C.opilio) in the eastern Bering Sea, and its use of defining management subareas. Can. J. Fish. Aquat. Sci., 38: 163-174

Vazzoler, A.E.A.M. (1996), Biologia da reprodução de peixes teleósteos: teoria e prática. Editora da Universidade Estadual de Maringá. 196

Wootton, R.J. (1990), Ecology of Teleost Fishes. Chapman and Hall, London. 404

Worthmann, H. (1979), A relação entre o desenvolvimento do otólito e o crescimento do peixe como auxílio na distinção de populações de Pescada (Plagioscion squamosissimus). Acta Amazônica, 9(3): 573-586 